\title{
Racial Disparities in the United States Criminal Justice System: "With Liberty and Justice for All?"
}

\author{
Remi Alapo, David Rockefeller \\ Institute for Peace and Leadership Inc., New York, USA
}

\begin{abstract}
Racial discrimination remains a prevalent issue in the contemporary U.S. despite efforts to promote equality. Many young African American and Hispanic males are easy target for law enforcement agents. Minorities experience a higher and more unfair form of racial discrimination, racial profiling, police brutality, unfair sentencing, and mass incarceration for offences which are the same or less than those committed by White males. The rate of incarceration in the United States is five to eight times higher than most developed countries, and Black males constitute the largest percentage of inmates in the U.S. prison system. Once arrested, Black Americans are more likely to remain in prison longer, and await trial for minor offenses at a higher rate than Whites. Black and Latino males sentenced in state and federal courts face significantly greater odds of incarceration than White offenders for the same or even higher crimes. Vagins and McCurdy in a 2006 ACLU on “cracks in the system” reported that "There is no rational medical or penological reason for the 100:1 disparity between crack and powder cocaine and instead it causes an unjustified racial disparity in our penal system” (p. 7). There is a racial disparity in the proportion of Black males in prison serving sentences of life without the possibility of parole (LWOP). In addition, The United States Criminal Justice System needs to be carefully examined as a top priority agenda needing immediate call of action that needs reform to guarantee the constitutional rights accorded to every American "with liberty and justice for all”.
\end{abstract}

Keywords: civil rights, civil liberties, criminal justice reform, racial inequalities, Fair Sentencing Act (FSA), mass incarceration, racial discrimination, prison privatization, racism, racial disparity, racial justice, reparations, Senate Bill S6098A, U.S Criminal Justice System, U.S. Prison System

\section{Racial Disparity in the Criminal Justice System}

According to Wing (2017), the United States is the world leader in putting her own population in prison. Wing also posited that while African Americans comprise 13 percent of the U.S. population and 14 percent of the monthly drug users, they are 37 percent of the population arrested for minor offences related to drug possession. Once arrested, Blacks are more likely to remain in prison longer, and await trial for minor offenses at a higher rate than Whites. Blacks are also 33 percent more likely to be detained and awaiting felony trials than Whites who are facing felony trials.

Remi Alapo (Ph.D.) is the Executive Director of Institute for Peace and Leadership, Inc., New York. She also teaches Race and

Ethnicity and Social Inequality in the Social Sciences Department at Bronx Community College, New York, USA.

David Rockefeller, is a Consultant with Institute for Peace and Leadership, Inc.

We thank the following from Bronx Community College (CUNY), New York, USA for their contributions to the roundtable discussion: Ines Adams, Kadiatou Bah, Williams Christopher, and Kimashallie Villanueva. 
In the past few years, Police stopped Black and Latino males at an alarming rate and higher than most White criminals. In New York City alone, where people of color make up more than half of the population, $80 \%$ of the NYPD routine checks were of Blacks and Latinos. When Whites were stopped, only 8\% were frisked. When Black and Latino males are stopped, $85 \%$ of them were frisked according to information provided by the NYPD. (Quiqley, 2011, para 6)

Zimmer and Hansen (2018), posited in a recent report than even though "stop and Frisk" is over in New York City under the de Blasio administration, Blacks and Latinos continue to be the population with the highest targets for stops and searches by the New York City Police Department. It was reported that there has been a significant drop in the number of stops by NYPD since a groundbreaking federal lawsuit deeming the tactics of "frisks" unconstitutional for low level stops. Sentences to be served by Black males in the federal prison system are nearly 20 percent longer than those for White males convicted of similar offenses. It is believed that race does play a significant role in how homicide cases are determined which often results in death sentences committed to the life of Black and Latino offenders.

The ACLU reported that Black and Latino males sentenced in state and federal courts face significantly greater odds of incarceration than White offenders for the same or even higher crimes. For example, there is a racial disparity in the proportion of Black males in prison serving sentences of life without the possibility of parole (LWOP). Nellie (2016) of the Sentencing Project discussed that,

\footnotetext{
African Americans are incarcerated in state prisons at a rate that is 5.1 times the imprisonment of whites. In five states, (Iowa, Minnesota, New Jersey, Vermont, and Wisconsin), the disparity is more than 10 to $1 \ldots .$. In twelve states, more than half of the prison population is black: Alabama, Delaware, Georgia, Illinois, Louisiana, Maryland, Michigan, Mississippi, New Jersey, North Carolina, South Carolina and Virginia. Maryland, whose prison population is 72\% Africa American, tops the nation...In eleven states, at least 1 in 20 adult black males is in prison. (para 5)
}

In 2009, the population of Black America was 13 percent, but as of 2012, this population represented 65 percent of prisoners serving life sentences for non-violent crimes. Marc Mauer of the Sentencing Project reported that African Americans are 21 percent more likely to receive mandatory minimum sentences than Whites, and 20 percent more likely to be sentenced to prison than White drug offenders. "In 2010, 85 percent of the 30,000 people sentenced for drug offenses were Blacks” (ACLU, 2014, p. 2).

\section{The War on Drugs}

It is through the policies that were enforced by President Reagan's "War on Drugs" administration, and mass incarceration of minorities that have allowed racial inequality to exist within the criminal justice system today. The types of legislation and policies enforced by an administration can help to perpetuate racial inequality within its criminal justice system. In the past, unfair criminal justice policies have been used the government in targeting certain racial and ethnic minority groups, criminalize the perpetuators of crime, and influence what the media presents to the public. The American Civil Liberties Union (ACLU), in a report to the Inter American Commission on Human Rights of October 2014, stated that "There are significant racial disparities in sentencing decisions in the United States, especially for the "war on drugs".

The "War on Drug” campaign was never intended to end crime, drug use, or deviance, but was a racially motivated tactic to put Blacks and Latinos, especially Black malesfrom actively functioning in the society. During the 1980s, crime rates and drug usage in America were on the rise. President Reagan passed a legislation that created stringent penalties for the possession and selling of crack and powder cocaine. This established the sentencing disparity between the two offenses (Lobianco, 2016). The policy was called the 
Anti-Drug Abuse Act of 1986. It was stated in this “A comprehensive examination of the 100-to-1 crack versus powder cocaine sentencing disparity under which distribution of just 5 grams of crack carries a minimum 5-year federal prison sentence, while distribution of 500 grams of powder cocaine carries the same 5-year mandatory minimum sentence” (Vagins \& McCurdy, 2006, p. 4). The Anti-Drug Abuse Act of 1986 imposed longer sentences for African Americans who used or had the possession of crack and lesser sentencing for White Americans who used powdered cocaine. With this policy, the impression that was being portrayed by the media to the American public was that the majority of Black Americans were drug users, even though there were significant number of White Americans engaged in these activities, such as in thepossession, sale, and in the use of these substances (Fosten, 2016).

\section{Privatization of the Prison System}

Prisons are a big business in the United States. A majority of prisons are privately owned and individuals thatare in charge of these prisons have two goals in mind: (1) prisons are a means of cheap labor for the production of many goods; and (2) the profits that can be obtained from those incarcerated by private prison owners (Aman \& Greenhouse, 2014). For example, prisoners may be recruited to provide such services as building roads, and bridges or other contract jobs obtained by the private sector. The privatization of the prison system in the United State is not different from the dynamics between the Bourgeoise and the Proletariat. The Bourgeoiseis the business owner, and part of the elite class that controls the means of production. While the Proletariats, are the labor force that produce products, that the Bourgeoise will exploit and use for profit.

In her 2018 article "The Problems with Private Prisons”, Joy Tara of the Justice Policy Institute posited that prisoners are exploited by the state as well as the elite class who owns private prisons. These prisoners are in creating products or in providing services that will not directly benefit their individual need, but rather, products and services that will alienate them further from others and society at large. An act prevents many minority males from the abilityof movingup higher on the social and economic class ladder and in achieving the "American dream”.

America's prisons have produced a new social group, a group of social outcasts who are joined by the shared experience of incarceration, crime, poverty, being classified as racial minorities, and have low level of education. As an outcast group, the men and women in our penal institutions have little access to the social mobility available to the mainstream. (Western \& Petit, 2010, para 1)

Prisons are under the regulation of the state, federal government, and under the ownership of the private sector (Aviram, 2016). The privatization of prison services creates racial inequality within the prison system itself creates disparities in the ways in which sentences are handed down to certain color of people. Mass incarceration has been used as a means in exploiting incarcerated prisoners. Thereby, making the United States Criminal Justice System distinctively a very corrupt one. Smith (2019) stated that

...in 2016 there were 128,063 people incarcerated in private prisons in the United States. This totals up to 8.5\% of the total federal and state prison population in the nation. Over the last two decades, this number has increased over $50 \%$ and most of those people are Black and Brown. It is not just a form of penal retribution...but a legalized form of slavery. (para 1)

The prison industrial complex can be considered a form of legalized modern-day slavery, because even 
though prisons provide services to prisoners, it is mainly at cost and at the expense of inmates.Prison privatization has been used as a means of repressing many racial and ethnic minority groups especially African Americans, to keep them in a lower social-economic status as well as at a lower social class.

\section{Mass Incarceration and Racial Injustice}

In Born SUSPECT: Stop-and-Frisk Abuses \& the Continued Fight to End Racial Profiling in America, the NAACP in 2014 reported that racial profiling is a daily reality for many people especially black men in communities of color and that even though the United States Constitution guarantees "equal rights, liberty and justice” for all, black and Latino males disproportionately are profiled more often than white males. Racial profiling assumes that a person is a suspect or it is assumed that certain populations in society are likely to commit certain types of crimes even when they have not actually committed those crimes or have any prior criminal records. Proponents of racial inequality and a chance to reform the criminal justice system of the United States will argue that the numbers reflect equal crime rate statistics for both Black and White communities in America. This is false and can easily be proven by closely analyzing data collected and published by the Federal Bureau of Investigation (FBI).

According to the 2016 Uniform Crime Reporting data report by the FBI, "70 percent of arrests made were of White Americans, 26.2 percent were of Black Americans,while 3.6 percent were of other races". If these data collected and presented by the FBI were properly justifiable, it should be observed that if the statistics of the incarceration rates presented are merely reflecting crime rates by race, then White Americans should make up 70.2 percent of the U.S. prison population based on their populace. Instead, White America only make up about 30 percent of the prison population for all arrests and crimes in America, while Black America makes up almost 70 percent of the prison population, even though they are only 26.2 percent of the people arrested for crimes. In addition, in 2017, the FBI reported that all arrests made based on hate crimes involved 50.1 percent of White people and only 20.3 of Blacks (FBI: UCR 2017-2018). These crime statistics prove without any doubt of the racial disparity in the United States criminal justice system.

New York State, in the move to become the first state to deconstruct privatization of the prison system, has a bill that was proposed in 2007 and believed to be the first course of action in prohibiting the private sector from operating prisons within its state boundaries. According to Smith (2019),

Since 2007, Assembly member Ortiz and State Senator Nozzolio introduced a bill entitled A 4484-B/S4118 that made New York a unicorn in this space. Along with two other states, The Empire State does not allow the operation of private prisons within the state prison systems-though some contracts are still allotted to private companies. The bill states the following: "in the effort forced upon state and local governments to cut operating costs, some are turning to the privatization of prisons the prison system”. (para 4)

As discussed earlier, the mass incarceration of minorities especially of African Americans in the prison industrial complex allows for racial disparities to exist, because the prison system is dependent on the exploitation of African American and Hispanic males who make up the largest population within the American prison system, who are used for cheap labor and high profits by both the federal, state and private sector alike. For example, Warde (2013), posited that Black males are disproportionately incarcerated compared to other racial and ethnic groups at an alarming and higher rate than whites. According to a 2014 report by the American Psychological Association, the United States has the highest incarceration rate in the world. 
While the United States has 707 incarcerated people per 100,000 citizens, for example, China has 124 to 172 per 100,000 people and Iran 284 per 100,000. North Korea is perhaps the closest, but reliable numbers are hard to find; some estimates suggest 600 to 800 per 100,000. (p. 56)

Mass incarceration in the United States is highly related to race, and economic and social class. Police tend to target mainly African American and Latino males from low income communities. The economic and social class inequalities that exist within the prison system are reflective of the level of education attained by many people of color within their communities (Western \& Pettit, 2010). For example, most people who are incarcerated are young Black and Latino males who are usually on the streets, may have a low level of education, no employment, and try to make a living doing one type of odd and end type of activity or the other. The reason why many Blacks and other minorities deviate towards a lifestyle of crime and deviance is the connotation of the "American dream". There is unequal distribution of resources in low income communities, relegating Black males to the back of the socio-economic development ladder where opportunities for advancement are incomparable to those available to White males. The concept of employment is also affected by mass incarceration. Former inmates usually experience a harder time assimilating back into the mainstream society and find it very difficult in obtaining adequate employment because of their previous criminal records.

In the final months of the Obama administration, the Justice Department concluded that private prisons were more dangerous and less effective at reforming inmates than facilities run by the government. After a year-long review, the Justice Department made a decision to start phasing private prisons out. But the Trump administration reversed that pledge, arguing that the Obama-era directive "impaired" the ability of the Federal Bureau of Prisons - which runs all federal prisons- "to meet the future needs of the federal correctional system" (Trilling, 2017). The ACLU reported that African American males are continually exploited and oppressed through the means of mass incarceration. Some progress has been made, however, because in 2010, the United States Congress passed the Fair Sentencing Act (FSA). This Act represented a bipartisan effort that was aimed at reducing the racial disparities that were caused by the war on drug sentencing laws, especially with the minimum mandatory sentencing. This Act, a guideline on sentencing, considered by many advocates of criminal justice reform as a direction in the right step, was a decade long effort to restore trust in the criminal justice system by communities of color. "In 2014, an amendment was made to apply reduced sentencing guidelines for people serving nonviolent drug sentences-85 percent of whom were Black Americans” (Grawert, Camhi, \& Chettiar, 2017, p. 11). While this seems like a good thing for the 85 percent of prisoners who are Blacks, this is only a "guideline" with the intension for federal judges to "begin" the process for hearing cases of non-violent offenders which may take years to determine the type of sentencing that are appropriate for each case.

On May 16, 2019, the New York State Senator James Sanders, Jnr. of the 10th District proposed Senate Bill S6098A, establishing the New York state commission to end mass incarceration and to prevent violence. The Bill is currently under consideration, and, as of July 23, 2019 former Vice President, Senator Joe Biden also "has unveiled a comprehensive plan aimed at combating mass incarceration and reducing racial, gender and income-based disparities in the system" (Glueck, 2019). The consequences of mass incarceration lead to African American and Hispanic males having a harder time assimilating back into society, finding employment, and living normal lives because of the racial disparities that exist within the criminal justice systems turning them into social outcasts, losing out in the many available opportunities to the mainstream, years after serving out their sentences. 


\section{Conclusion}

Racial discrimination remains a prevalent issue in the contemporary U.S. despite efforts to promote equality. It is evident that the racial disparities that exist in the criminal justice system of the United States of America has significantly limited many minorities especially the Black American male's capability to move to a competitive social-economic class, further impeding on his ability to achieve the "American dream". The Fair Sentencing Act amendment was made to apply reduced sentencing guidelines for people serving non-violent drug sentences. While this seems like a good thing for the 85 percent of prisoners who are Blacks, this is only a "guideline" with the intension of federal judges to "begin" hearing cases of non-violent offenders which may take years to conclude and determine the appropriate type of sentencing for each case. This step seen by many as a step in the right direction may further alienate young Black males from the society. The recent Senate Bill S6098A that was proposed in May of 2019 to end incarceration and prevent violence, and the comprehensive plan aimed at combating mass incarceration and reducing "racial, gender and income-based disparities in the system” unveiled by former Vice President, Senator Joe Biden is still under consideration. The criminal justice system therefore needs to be carefully examined as a top priority agenda needing immediate call of action that needs reform to guarantee the constitutional rights accorded to every American "with liberty and justice for all”.

\section{References}

Aman Jr., A. C., \& Greenhouse, C. J. (2014). Prison privatization and inmate labor in the global economy: Reframing the debate over private prisons. Fordham Urban Law Journal, 42(2), 355-409. Retrieved July 5, 2019, from https://search-ebscohost-com.ccnyproxy1.libr.ccny.cuny.edu/login.aspx?direct=true\&db=a9h\&AN=102838992\&site=ehost-live

American Civil Liberties Union (ACLU). (2014). Racial disparities in sentencing: Hearing on reports of racism in the justice system of the United States submitted to the Inter-American Commission on Human Rights 153rd session. Retrieved June 5, 2019, from https://www.aclu.org/issues/racial-justice/race-and-criminal-justice

American Psychological Association (APA). (2014). The United States leads the world in incarceration: A new report explores why and offers recommendations for fixing the system. Incarceration Nation, 45(9), 56. Retrieved July 5, 2019, from https://www.apa.org/monitor/2014/10/incarceration

Aviram, H. (2016). Are private prisons to blame for mass incarceration and its evils? Prison conditions, neoliberalism, and public choice. Fordham Urban Law Journal, (42), 2. Retrieved June 5, 2019, from https://ir.lawnet.fordham.edu/ulj/vol42/iss2/2/

Equal Justice Initiative. (2017). Mass incarceration costs $\$ 182$ billion every year, without adding much to public safety. Retrieved June 5, 2019, from https://eji.org/news/mass-incarceration-costs-182-billion-annually

FBI Criminal Justice Information Services Division (CJIS). (2017). Hate Crime Statistics. Retrieved June 5, 2019 from https:/uce.fbi.gov/hate-crime/2017/topic-pages/offenders

FBI Criminal Justice Information Services Division (CJIS). (2016). 2016 crime in the United States. Retrieved June 5, 2019, from https://vcr.fbi.gov/crim-in-the-u.s/2016/crime-in-the-u.s.-2016/topic-pages/tables/table-21

Fosten, G.K. (2016). Perspectives on social inequality, criminal justice, and race in the United States: A critical analysis. Journal of Pan African Studies, 9(9), 122-141. Retrieved July 15, 2019 from http://ccnyproxy1.libr.ccny.cuny.edu/login?url=https://search.ebscohost.com/login.aspx?direct=true\&db=a9h\&AN=1200464 63\&site=ehost-live

Glueck, K. (2019). Biden, scrutinized for crime bill, unveils plan to reduce mass incarceration. The New York Times. Retrieved June 25, 2019, from https://www.nytimes.com/2019/07/23/us/politics/biden-criminal-justice.html

Grawert, A. C., Camhi, N., \& Chettiar, I. (2017). A federal agenda to reduce mass incarceration. Brennan Center for Justice 20 Years at New York University School of Law. Retrieved from https:/www.brennancenter.org/sites/default/files/publications/a\%20federal\%20agenda\%20to\%20reduce\%20mass\%20incarc eration.pdf

Jarman, J. (2016). Social inequality and its consequences in the twenty-first century. Journal of the Academy of Social Sciences, 
11(2-3), 103-112.

Joy, T. (2018). The problem with private prisons. Justice Policy Institute. Retrieved June 5, 2019, from http://www.justicepolicy.org/news/12006

LoBianco, T. (2016). Report: Nixon's war on drugs targeted black people. Retrieved April 16, 2019, from https://www.cnn.com/2016/03/23/politics/john-ehrlichman-richard-nixon-drug-war-blacks-hippie/index.html

Mauer, M. (2018). Long term sentences: Time to reconsider the scale of punishment. UMK Law Review, (87), 1. Retrieved June 5, 2019, from https://www.sentencingproject.org/publications/long-term-sentences-time-reconsider-scale-punishment/

NAACP. (Sep. 2014). Born SUSPECT: Stop-and-Frisk Abuses \& the Continued Fight to End Racial Profiling in America. Baltimore: $\quad$ Maryland. Retrieved July $\quad 30, \quad 2019$ from https://www.prisonpolicy.org/scans/naacp/Born_Suspect_Report_final_web.pdf

Nellis, A. (Jun. 2016). The color of justice: Racial and ethnic disparity in state prisons. The Sentencing Project. Retrieved July 30, 2019 from https://www.sentencingproject.org/publications/color-of-justice-racial-and-ethnic-disparity-in-state-prisons/

Quigley, B. (2011). Fourteen examples of racism in criminal justice system. Huffpost. Retrieved June 5, 2019, from https://www.huffpost.com/entry/fourteen-examples-of-raci_b_658947?

Smith, N. D. (2019). New York State deconstructs private prisons: Becomes first state to make move. Retrieved July 25, 2019, http://thesource.com/2019/06/24/new-york-state-private-prisons/

Trilling, D. (2017). Private prisons: Research, data and controversies. Retrieved June 5, 2019, from https://journalistsresource.org/studies/government/criminal-justice/private-prisons-research-data-lobbying/

Vagins, J. D., \& McCurdy, J. (Oct. 2006). Cracks in the System: Twenty Years of the Unjust Federal Crack Cocaine Law. American Civil Liberties Union (ACLU). Retrieved on August 31, 2019 from https://www.aclu.org/other/cracks-system-20-years-unjust-federal-crack-cocaine-law

Warde, B. (2013). Black male disproportionality in the criminal justice systems of the USA, Canada, and England: A comparative analysis of incarceration. Journal of African American Studies, 17(4), 461-479. Retrieved from https://doi.org/10.1007/s12111-012-9235-0

Western, B., \& Pettit, B. (2010). Incarceration \& Social Inequality. Daedalus, 139(3), 8-19. Retrieved from https://doi.org/10.1162/DAED_a_00019

Wing, K. (2017). This chart shows why it's so hard to tackle mass incarceration in America. Huffpost Politics. Retrieved June 5, 2019, from https://www.huffpost.com/entry/mass-incarceration-chart_n_58c9636ce4b022994fa3ee27

World Prison Brief. (n.d.). Highest to lowest-Prison population rate. Retrieved June 7, 2019, from http://www.prisonstudies.org/highest-to-lowest/prison_population_rate?field_region_taxonomy_tid=All

Zimmer, K., \& Hansen, E. (Jun. 2018). 'Stop and Frisk’ is Over, But Low-Level NYPD Encounters Now Raise Concerns. City $\begin{array}{lllll}\text { Limits.org.Retrieved July } & 29, & 2019\end{array}$ https://citylimits.org/2018/06/21/stop-and-frisk-is-over-but-low-level-nypd-encounters-now-raise-concerns 